\title{
GLOBALISATION BROUGHT INTO THE CLASSROOM - REFLECTIONS FROM THE LOCAL CONTEXT IN SOCIAL WORK AND NURSING EDUCATION
}

\author{
Irena Dychawy Rosner, Jonas Christensen \\ Malmö University
}

\begin{abstract}
In increasingly globalised societies higher education meet challenge to integrate the international and intercultural dimensions into their services, strategic plans, education programmes and research. There were few discussions around the concept of "Internationalization at home" ( $\mathrm{IaH}$ ) during the last years in the academic community. This article generally outlines a process of IaH in higher education, by giving examples from the bachelor programmes of Social Work and Nursing Education at Malmö University, Sweden. The internationalisation of the curriculum at home was shown to have a much greater impact than individual mobility alone. The authors of the article present their own analysis about possibilities to understand the culture, profession in the process of IaH improving professional and intercultural competences. Modern society poses a challenge for professionals - to think globally and to act locally.

KEYWORDS: higher education, internationalization at home ( $\mathrm{IaH}$ ) social work, nursing, intercultural competences, global, glocal.
\end{abstract}

\begin{abstract}
Anotacija
Globalejjančioje visuomenejje aukštasis mokslas patiria nemažai iššūkių: integruoti tarptautines ir tarpkultūrines dimensijas ị švietimo paslaugas, strateginius planus, studijų programas ir mokslinius tyrimus. Pastaraisiais metais šis klausimas akademinejje bendruomenejje gana dažnai aptarinèjamas. Šis straipsnis atskleidžia internacionalizacijos procesą aukštajame moksle namuose (IAH), kaip pavyzdi pateikiant socialinio darbo ir slaugos bakalauro studijų programas, kurios vykdomos Malmès universitete, Švedijoje. Internacionalizacijos namuose ugdymo turinys atskleide, kad šis procesas daro daug didesni poveikị nei individualus mobilumas. Straipsnio autoriai pateikia savo požiūrị, kaip galima suprasti kultūrą, profesiją internacionalizacijos namuose aspektu ịtvirtinant tiek profesines, tiek tarpkultūrines kompetencijas. Šiuolaikinè visuomenė kelia specialistams uždavinị mąstyti globaliai ir veikti lokaliai.

PAGRINDINIAI ŽODŽIAI: aukštasis mokslas, internacionalizacija namuose, socialinis darbas, slauga, tarpkultūinès kompetencijos, globalus, glokalus.
\end{abstract}

DOI: http://dx.doi.org/10.15181/tbb.v74i2.1364

\section{Introduction}

Transcultural competence is acknowledged as a very important tool for health care and social work professions, in order to prepare students for diverse client populations. According to Stier (2006), it can be described as knowledge about, and ability in, international relations; for example, foreign language skills and/or knowledge about the political, social, and economic development of countries or 
regions which lead to the development of understanding, respect, and empathy for people with different national, cultural, social, religious, and ethnic origins. Historically, this diversity was referred to through racial or ethnic differences, such as nationality, religion and others. Since the 1980 s, this character has expanded to promote an awareness of multiple forms of internationalisation and globalisation. The most recent higher education strategy at the European level articulates the importance of those graduating within the European Higher Education Area to have had a period of study or training abroad (CEC, 2009). Nowadays, the growing research on higher education in the fields of social work and nursing highlights the value of internationalisation in professional development (Lyons, Hokenstad and Pawar et al, 2012). The internationalisation of higher education can be understood as a multifaceted phenomenon, including administrative, educational joint projects and research exchanges. Participation in international academia provides access to globalising academic communities, that may assist individuals to expand and enrich their critical international perspectives, practices and identities. Social workers and health care staff have wide-ranging responsibilities, and it is important for educational programmes to include accounts of global social conditions, health and welfare systems (Healy, 2008). For example, the education of those in the "helping professions" emphasises transcultural identities, such as religious orientation and family cultural characteristics, as important when preparing interventions with clients from different cultures. The need for international influence in social work and health care education is clear, although achieving it may be compound (Merrill and Frost, 2011).

Many researchers claim that the impact of ongoing global processes in contemporary societies calls for the reformulation of educational programmes to include more international and cross-border cultural content (Nagy and Falk, 2000; Parker and McMillan, 2007). A growing demand among employers for internationalised graduate is making it increasingly common for graduates to gain experience outside their home countries, while those remaining within their home country are more likely to interact with colleagues, customers or suppliers elsewhere in the world, or at least, with culturally diverse individuals in their own countries. As a result, universities perceive themselves to be under pressure to equip their graduates to compete in global labour markets, with the associated benefits to the university in terms of rankings, reputation and international mobility. These related trends set the scene for the educational concept of 'internationalisation at home' (IaH): that home students are able to take part in an international educational programme, despite their own lack of interest in taking part in the mobility. There are various differences in the focus of internationalisation, depending on the perspective taken on the existing educational environment. For example, internationali- 
sation is defined as the process of integration of an international dimension into the research, teaching and services function of higher education (Nilsson, 2003). Further, De Wit (2002) acknowledges four broad categories of rationales for internationalisation that are connected to political and economic, social, cultural, and academic features, all of these encompassing the realities of higher education. These contextual dimensions may vary in importance by country or region, and their dominance over the process of internationalisation in higher education may, in fact, change over time.

The dimensions described by Stier (2006), acknowledge the various aspects of internationalisation and how it evolves to levels in the internationalisation of higher education. One of these aspects includes activities aiming to help students develop international awareness and intercultural competence skills (Dychawy Rosner, 2013). These aspects are much more curriculum-oriented, and prepare students to be aware of the increasingly globalized world. They may include work as regards the development of internationalized curriculum content, or international materials in teaching, as well as an international perspective in the arrangement towards students' learning processes. The other aspects contain all forms of education across borders. They may be directed towards providing an exchange between students and academic staff, or involve a variety of mobility projects between universities and educational programmes. These components should not be considered mutually exclusive, but rather intertwined within a university's existing policies and educational programmes.

For social work and nursing education, courses which prepare students to support vulnerable and unwell populations in contemporary multi-cultural societies, it is important to enable students' knowledge of a wider social and cultural context during their studies (Aliakbari, et al., 2015). In this article, the two terms - intercultural skills and transcultural meetings - are used to describe a focus on intercultural and transcultural dimensions embracing both students and the process of learning in international classrooms, at home. The fact that the students have different educational backgrounds and represent experiences of different traditions is seen as a resource in education. As the authors see it, this is because they enrich and strengthen each other in order to discuss internationalisation in full. However, from the $\mathrm{IaH}$ perspective, it is rare that attention is paid to how transcultural classrooms have created educational communities of practice and thereby changed the individual positions of development formulated by the creation of social networks and the variety of subcultures in transcultural education. The didactical dimensions and curriculum perspectives, to our knowledge, are also generally lacking in current research. The purpose of this article is to reflect on the work of internationalisation brought to the classroom in the fields of social work and nursing education, connected particularly 
to the implementation of two courses: "Social Policies in Europe" and "Transcultural Nursing". The arguments developed in this article are drawn from analysis and teaching experiences conducted as quality improvement, taken from two course evaluations. Our reflections focus on the student-centered perspective in terms of a two-dimensional approach: the composition of the IaH classroom, and transcultural education as a pedagogical resource (Emmanuel, 2012). The perspectives presented in this article are based on the synthesis of some of the main characteristics of $\mathrm{IaH}$ profiles, related to everyday educational practice, offered to first cycle students at the faculty of Health and Society, Malmö University, Sweden. The university is strongly connected to the local region and promotes the internationalisation of curricula and exchange programmes for teaching staff and students (Malmö University, 2013). However, the university also offers internationalisation studies at home (Nilsson, 2003), which benefits students as it provides access to expertise that exists across the internationally provided network.

\section{The shape of an IaH transcultural classroom}

The IaH approach is a way to discuss and reflect on internationalisation in the classroom, not a theory that is made up of testable hypotheses. This is exemplified by two courses conducted at the bachelor professional degree level, shown in figure 1. These courses should be seen as concrete examples of IaH classrooms in which students' participation $(n=95)$ comes from both partner universities and some students even applied as free-movers. The courses were not formally connected to each other. The Social Policies in Europe course was a two-week intense campus-based course, in which 50 social work students from various countries met with facilitators. A mixture of lectures and workshops focusing on comparative aspects of social policy took place during these two weeks, thereafter an onlinebased element continued the course, which was seven weeks long altogether.

The transcultural nursing course was also an intense campus-based course, lasting two weeks, with 45 enrolled students from Sweden, Holland, Belgium and Norway. The campus period was followed by a three week-slot for individual writing focusing on transcultural components in nursing. The course curriculum was developed as a part of a deeper collaboration between Tellemark University College, Hanza University School of Applied Sciences and University College of Leuven. The course was conducted simultaneously in Malmö, Tellemark and Groningen, and its realisation included the exchange of both students and teachers, with 15 participating students in each class (Dychawy Rosner, 2012). The course content, which considered the core of actual transcultural nursing practice, was based on a framework suggested by Camphina-Bacotte and Munoz (2001). 
Course

Transcultural

Nur- The course curriculum aims to give the students theoretical sing - provided as a and practical foundations for their professional role, related jointly developed curri- to the on-going process of varying transcultural conditions cula with partner institu- for an individual, family or society, with a particular focus on tions

Social Policies in Eu- The course curriculum aims to develop the students' knowledge rope - provided as a and understanding in relation to social policies within a European single subject course at context, with a particular focus on the relevance for social work the faculty and their implications for social work practice.

Figure 1. The summary of IaH courses contents

Integrating an international and intercultural dimension into the content and materials of both courses, as well as teaching and learning activities, was the most important strategic component in the development of an IaH education in the presented course modules. The majority of the students in both courses came from European universities. Both exemplified courses conducted with IaH in mind, by infusing the existing curricula with diverse perspectives and target knowledge gathered from professional practice across cultures and countries. This resulted in a reconceptualisation of traditional subject areas, such as considering clients' needs, to include transcultural communication skills and the opportunity to learn interrelationships between local and international social and health care policy and social care issues that affect professional practice. The format for the assessment of student performance included traditional lectures, seminars, problem-based learning, field studies and individual written tasks. The focus of the assessment was based on the student's ability to argue and justify choices made in professional social work and nursing and to reflect on these choices and consequences.

\section{IaH as a pedagogical resource}

Internationalisation's support of the mission of these courses focused on promoting cross-border mobility, knowledge transfer and, throughout, an analysis of course content and progression levels. Further on, it had a role in jointly solving the problems related to the creation of togetherness, and the processing of social networks. As shown in figure 2, the IaH pedagogic resource was a creation of didactics such as the promotion of togetherness, the stimulation of reflexive activities, and also by building up shared learning activities. According to Shring and Shrestha (2008), the main aim of the international classroom could be to become 
a place where, through the interaction of knowledge, shared ideas and theories from multiple cultural contexts (that, further, are explored and scrutinized through intercultural engagement) the participants, their disciplines and their professional practices all gain new knowledge in action.

The pedagogical resources involved two cornerstone aspects: teaching strategies and teaching transactions. Teaching strategies were directed towards the creation of togetherness, enabling possibilities for dialogue and reflexivity. This involved building shared activities securing equal participation and inclusion into the course schedules. Teaching transactions comprised practical ways to socialise and communicate with one another as the students interacted with each other.

Internationalisation is a flow of ideas and values as well as a consideration of people's impact on what happens locally. We consider these issues as very important to and to bring these joining perspectives to the classroom as a base to create contextually relevant teaching and learning. Classroom dynamics were created by infusing intercultural issues and existing differences politically, socially and personally into instructional design and into the students' actions. The theoretical framework on international education, as well as on the local contexts of the participating students, was based on knowledge from research, literature and multidisciplinary conceptions of internationalisation (Barnett, 2000; Camphina-Bacotte and Munoz, 2001; Merrill and Frost, 2011). Students acquired the necessary information, knowledge and understanding of the topics they were studying through three angles of didactics: the creation of togetherness forming them into a community of pedagogical practice; the stimulation of connectedness and reflexivity; and the sharing of responsibilities and learning activities.

In order to outline what Barnett (2000) terms as the "super-complexity" of university activities, the pedagogical classroom of these creative contexts has been characterised by two major approaches, roughly divided between the focus on student groups and their learning processes, plus the development of learning objectives, followed by the organisation of new learning environments. The classroom pedagogy, teaching values and strategies largely moved from text-bound didactics to discussion, collaboration and communication among students and teachers. The IaH classroom was created as a pedagogical resource functionally approached through cross-border meetings, where social, organisational and cultural aspects come together. The education itself and the learning environment, in this context, were therefore closely linked to each other. In the encounter between the individual and the learning process, students have incentives, governance, and social support within a course framework which was of great importance for knowledge acquisition (Merrill and Frost, 2011). To our knowledge, we need to find new ways of educating students, and herein, transcultural ways of educating them, as it has 
been seen as sufficiently open to increased understanding from a multicultural perspective. Teaching critical practice towards social challenges to undergraduate students has to be linked to critical thought, in terms of, for example, empowerment perspectives and anti-oppressive practice, as well as how diverse backgrounds may operate under different cultural norms and an awareness of the student's own subjective constructions and personal attitudes (Morley, 2008). To enable students to gain knowledge and skills which will help them to possess an inter-cultural competence may present a challenge. For example, social work is considered to be bound to national traditions, laws and local cultures that make teaching adapt to local structures (Trygged and Eriksson, 2012).

Teaching strategies Teaching transactions

1. Creation of togetherness Grouping students for Peer Learning

Organising meetings for encounters between different socio-cultural aspects

Applying social networking technology and communication tools

2. Stimulating connectedness in reflexivity
Promoting a sense of classroom community as a shared learning environment

Making an instructional use of social exchange by mixing knowledge sharing from photos, associations, storytelling, MySpace and face-to-face interactions
3. Assurance of shared activities
Building up the sharing of responsibilities for learning and achievement goals e.g., problem-based learning Joint working through classroom projects, study visits Building local ties by open seminars between domestic and international students.

Figure 2. Summary of generic teaching strategies and transactions in the composition of an IaH classroom

Barnett (2000) considers learning as the acquisition of knowledge, requirement of dynamic relationship between an already "known" knowledge and "unknown" knowledge. In this perspective, students need to explore how they can raise an mutual understanding of a more global view, while at the same time, being aware of own different traditions and values. The importance of allowing students and teachers to meet on a cross-border basis, as in our study built upon internationalization at home, as a part of domestic local programs with global understanding, a glocalised view on professional skills, should not be underestimated when 
developing professional competence (Christensen, 2016). It is largely about how the students can turn obstacles into new opportunities for widening existing views or dare to go beyond the limits. Students arrived with views on certain things, such as their own profession, however the transcultural meetings in the classroom with others of the same profession were shown to strengthen their views on what they had in common together with providing an understanding of what differs in professional roles in the participating students' home countries. A high association barrier can be understood as helping us to structure the environment, focus thinking and solve problems using proven methods (Shu and Bazerman, 2010). In the process of knowledge development, it is the encounters between people of different backgrounds, cultures and frameworks that challenge a student's notions, not least in the classroom context. People can allow for new knowledge and tear down, or at least reduce, their association barriers in several ways: through exposure to different cultures and networks, by learning in other ways, or by turning away from assumptions and using different perspectives instead. To provide opportunities for a developed knowledge of, and readiness for, change, a development of competence in terms of developing new actions' and an openness to international perspectives at home was shown to be vital for students' awareness of personal and professional development and change. These learning experiences by students we have highlighted as local meetings and global awareness.

Local meetings and global awareness

Some researchers have examined the transformative effects of an international education (Sun, 2013). Our study showed that novel contexts, new roles and points of view change students' perspectives, to more towards new frames of reference and generate new understandings. Participating students were encouraged to undertake a process of becoming more aware of their personal orientation, according to their personal development and professional role. Some students pointed out that the opportunity to stay in Malmo and at the same time, still meet fellow students from other countries was an important part in getting a more global perspective on their professional role. This was expressed by some students: "It's important to gather many different impressions to get a good overview about social work and everything that belongs to it. Doing this at "home" when meeting students from abroad gives the opportunity to get a "bigger" view about the social work situation in Europe." The mixture of teachers in the classroom with different backgrounds also gave students various experiences from different disciplines, which was expressed as: "We have experienced how teachers, coming from different fields domestically and from abroad, have different perspectives on social work, [and how this] contributed and developed our own knowledge as students". 
The development of self-reflectiveness was shown to be an important key element in the student's professional awareness in defining and solving problems with, effectively, "new eyes".

The perspectives from the students on understanding increasing the nuances of their professional roles was expressed by both social work and nursing students. The students expressed that the transcultural meetings that occurred during the courses gave them more awareness on cultural issues. This kind of reasoning was strongly expressed by nursing students in terms of "opportunities to adapt to international nursing care standards", and "an awareness to [try to] understand the cultural influences in communicating with patients", or "[an] increasing impact on my potential for the possibilities for career plans and [which] may impede my employability abroad". Some students pointed out after having worked on a jointclass project that "we learnt through our cross-border cooperation to reflect on our own social system, to judge the advantages and disadvantages". The students' developing understanding of social issues and how they can be organized was raised by comments such as: "It's interesting to meet students from other countries, to hear how social work is organised and viewed there".

Encounters with other students of their own profession was strongly appreciated, as expressed by one student: "It let me see my profession from [the point of view of] a more collective assembly and I could adapt [a] more strategic professional outlook for transcultural health care". Moreover, the students pointed to participating in the exchange program, having extensive personal meetings and ongoing occurring discourses as a starting point for their personal growth when challenging their previous views on the risky nature of travelling and their provincial boundaries and desires to stay at home. However, our material also shows that there were some students who were not ready to leave their families and homes or willing to take job opportunities abroad. Secondly, in the cases where students clearly approved of a more strategic international career outlook, this was in relation to their values of social justice, a large number of travelling experiences, the acknowledgment of new communication technologies and an awareness of the growing importance of international knowledge related to the globalisation of societies.

\section{Discussion}

Gaining transcultural awareness through international encounters can be seen as epistemological form of attaining knowledge. Each of the educational programmes, in this case both social work and nursing, have norms in terms of what those undergoing education should be learning, and what the outcome of their 
learning should be. IaH classrooms' transcultural learning processes, in the sense of expanding students' explanatory power as a function of their professional roles, was found to be fundamentally constructed by the individual through his/her acts and interactions. Thus, there was an independent reality abroad, to weigh in on the individual's constructions of studied subject issues, embraced by socially-constructed understandings.

It has been argued that contemporary societies have shifted to being more multicultural, with existing global influences on the local level of living conditions. Our experiences of applying teaching related to internationalisation at home indicated positive encounters between the student, the world and society, mirrored by each person. The concept of IaH classroom practice was not born in the systems theory tradition. It has its roots

in attempts to develop accounts of the social nature of human learning, inspired by anthropology and social theory (Giddens, 1984; Foucault, 1980; Vygotsky, 1978). Nevertheless, the concept of community in IaH practice is well-aligned with the perspective of the systems theory tradition. A community of practice that occurs in the IaH classroom can be viewed as a simple social system. A community of IaH practice can therefore be understood as a social learning system, in which the practice through pedagogy and transcultural education gives students wider perspective, and prepares them for personal and professional development in a glocalised world.

This was emphasised by our students' comments, in which different aspects of their learning processes took place through transcultural meetings including social, academic and cultural dimensions. There is obviously a breaking-point and a decline, however where this certain point is defined requires further discussion, even though when students meet in the "international classroom", different kinds of exchanges take place. To a certain extent, this gives an added "learning" value, after which it is likely that there is a decreasing connection between how transcultural meetings may contribute value towards learning, which confirms in many ways what Barnett (2000) raises as the development of new learning-environment rooms. Scholars adopting a critical lens toward cultural competence and internationalisation often stress that its effects are difficult to measure due to the difficulties in defining educational goals and well-recognised types of competencies (Allen and Ogilvie, 2004). Additional critiques emerge from the limited empirical evidence for specificity needed to attain concrete practice objectives, as well as gaps between institutional rhetoric and action in educational everyday practice (Shulz, 2007). Nevertheless, the findings derived from the figures in our courses suggest that students could acknowledge and understand the application of global 
perspectives on local health and social care practices in their home countries, at both the personal and institutional levels.

\section{Conclusion}

In our examples, the internationalisation of the curriculum at home was shown to have a much greater impact than individual mobility alone. Home students were able to receive an international educational experience at home, and foreign students could receive deeper insights into locally-framed social and academic spaces. Providing the local and global issues in the classroom created an integration of knowledge and access to experiences across cultural boundaries that would not have been available for the students elsewhere. Notably, this includes intercultural exchange, as well as organised, internationally-themed opportunities for students to interact within the classroom as well as the situation of students within a globally framed context at home. With challenge-based learning as a guiding principle (Johnson Laurence et al., 2009), we approached actions which required students to be active and open-minded. Our IaH transformative learning approach could bridge, connect and help with meaning-making, for example, through the use of metaphors and study visits whereby students could make associations linked to images from their earlier frame of reference. In this study, it was shown that there is some positive transformation of learning connected to the creation of transcultural meetings and study. Hence, there is a need for further investigation on how teaching situations can raise students' understanding, and how they can widen their perspectives through the development of $\mathrm{IaH}$ in relation to the use of pedagogical tools to help people meet each other. By doing this, it will assist us in developing a more local and global understanding, and what we call a glocal construct of competence. In summary, we suggest three areas of consideration that may link the purposes of higher education with diversity and globalisation: the internationalisation of the curricula, the creation of an educational process in the classroom that emphasises a didactical dimension concerning internationalisation in higher education, and the adaptation of a transformative-learning approach, enabling students to shift their way of understanding the word. In this way, IaH learning can become an essential tool for reflecting on, and becoming aware of, how personal preferences and cultural biases may influence professional competencies, as well as helping students to develop intercultural capabilities when facing variability in their clients. 


\section{References}

Aliakbari, F., Parvin, N., Heidari, M., Haghani, F. (2015). Learning theories application in nursing education. Journal of Education and Health Promotion, Vol. 5(4), p. 2.

Allen, M., Ogilvie, L. (2004). Internationalisation of higher education: Potential and pitfalls for nursing education. International Council of Nurses, International Nurses Review, Vol. 51, p. 73-80.

Barnett, R. (2000). University knowledge in an age of super complexity. Higher Education, Vol. 40, p. 409-422.

Camphina-Bacotte, J., Munoz, C. (2001). A guiding framework for delivery culturally competent services in case management. The Case Manage, Vol. 12 (2), p. 48-52.

CEC. (2009). Promoting the learning mobility of young people. Brussels: Commission of the European Communities. COM, p. 329.

Christensen, J. (2016). Acting locally, thinking globally in social work education. International Journal of Social Sciences and Education Research, Vol. 2 (3), p. 1160-1173.

De Wit, H. (2011). Globalisation and Internationalisation of Higher Education. Revista de Universidad y Sociedad del Conocimiento (RUSC), Vol. 8 (2), p. 241-248.

Dychawy Rosner, I. (2012). Transcultural nursing: Annual report of the course. Malmö: Malmö University. Website: http://dspace.mah.se/handle/2043/13732

Dychawy Rosner, I. (2013). Social responsibility: Internationalisation of health care over a bridge. EAIE: Curriculum \& Teaching Mobility, Vol. 8, p. 21.

Emmanuel, J. F. (2012). Transcultural blended learning and teaching in postsecondary education. Oshkosh: University of Wisconsin.

Foucault, M. (1980). Power/Knowledge: selected interviews and writings. C. Gordon (ed.). New York: Pantheon.

Giddens, A. (1984). The constitution of society: outline of the theory of structuration. University of California Press.

Healy, L. (2008). International Social Work: Professional Action in an interdependent world. Oxford/New York: Oxford University Press.

Johnson, L. F., Smith, R. S., Smythe, J. T., Varon, R. K. (2009). Challenge-based learning - An approach for our time. Research Report. The New Media Consortium, p. 4-13.

Lyons, K. H., Hokenstad, T., Pawar, M. et. al (Eds.) (2012). The SAGE Handbook of International Social Work. London: Sage Publications.

Malmö University strategy 2020. (2013). Mah, No. 15-2013/117. Malmö: Malmö University.

Merrill, M. C., Frost, C. J. (2011). Internationalising Social Work Education: Models, Methods and Meanings. Frontiers: The Interdisciplinary Journal of Study Abroad, Vol. 21, p. 189-210.

Morley, Ch. (2008). Teaching critical practice: Resisting structural domination through critical reflection. Social Work Education, Vol. 27 (4), p. 407-421.

Nagy, G., Falk, D. S. (2000). Dilemmas in international and cross-cultural social work education. International Social Work, Vol. 43, p. 49-60.

Nilsson, B. (2003). Internationalisation at Home from a Swedish perspective: The Case of Malmö. Journal of Studies in International Education, Vol. 7 (1), p. 27-40.

Parker, V., McMillan, M. (2007). Challenges facing internationalisation of nursing practice, nurse education and nursing workforce in Australia. Contemporary Nurse, Vol. 24, p. 128-136.

Shu, L., Bazerman, M. (2010) Cognitive barriers to environmental action: Problems and solutions. Harvard: Harvard University Press.

Shulz, L. (2007). Educating for global citizenship: Conflicting agendas and understandings. The Alberta Journal of Education Research, Vol. 53 (3), p. 248-258.

Shring, M., Shrestha, M. (2008). International pedagogical Structures. In: M. Helsten, A. Reid (eds.). Researching international pedagogies, sustainable practice for teaching and learning in higher education. New York: Springer Science \& Business Media B.V, p. 65-82.

Stier, J. (2006). Internationalisation, intercultural communication and intercultural competence. Journal of Intercultural Communication, Vol. 11, p. 1-12.

Sun, Q. (2013). Learning for transformation in a changing landscape. Academic Journal of Adult Learning, Vol. 24 (3), p. 131.

Trygged, S., Eriksson, B. (2012). How do students perceive international dimension in social work education? An enquiry among Swedish and German students. Journal of Social Work Education, Vol. 48 (4), p. 655-667.

Vygotsky, L. (1978). Mind in society: development of higher psychological processes. Harvard: University Press. 